\title{
Flipside Theory: Emerging Perspectives in Literary Criticism
}

\author{
Chinedu Nwadike, Chibuzo Onunkwo*
}

Department of English \& Literary Studies, University of Nigeria, Nigeria

Corresponding Author: Chibuzo Onunkwo, E-mail: chibuever@yahoo.com

\section{ARTICLE INFO}

Article history

Received: June 18, 2018

Accepted: August 19, 2018

Published: November 01, 2018

Volume: 7 Issue: 6

Advance access: September 2018

Conflicts of interest: None

Funding: None

\begin{abstract}
Literary theories have arisen to address some perceived needs in the critical appreciation of literature but flipside theory is a novelty that fills a gap in literary theory. By means of a critical look at some literary theories particularly Formalism, Marxism, structuralism, poststructuralism, psychoanalysis, and feminism but also Queer theory, New Criticism, New Historicism, postcolonialism, and reader-response, this essay establishes that a gap exists, which is the lack of a literary theory that laser-focuses on depictions of victims of social existence (people who simply for reasons of where and when they are born, where they reside and other unforeseen circumstances are pushed to the margins). Flipside criticism investigates whether such people are depicted as main characters in works of literature, and if so, how they impact society in very decisive ways such as causing the rise or fall of some important people, groups or social dynamics while still characterized as flipside society rather than developed to flipview society. While flipside literary criticism can be done on any work of literature, only works that distinctively provide this kind of plot can lay claim to being flipside works. This essay also distinguishes flipside theory from others that multitask such as Marxism, which explores the economy and class conflict between the proletariat and the bourgeoisie, and feminism, which explores depictions of women (the rich and the poor alike) and issues of sex and gender. In addition, flipside theory underscores the point that society is equally constituted by both flipview society and flipside society like two sides of a coin.
\end{abstract}

Key words: Flipside Theory, Literary Criticism, Literary Theory

\section{INTRODUCTION}

Literary theory and literary criticism have accomplished such magnificent tasks in literature that despite critical shortcomings found in each of them which seem to undermine their greater merits, they will continue to play the vital roles they have been playing. In addition, it is arguable, as Terry Eagleton declares, that "Some texts are born literary, some achieve literariness, and some have literariness thrust on them" (7).

The reading of a literary work from a particular point of view makes it an eclectic approach even when this approach is a combination of two or more points of view. In this lies probably the greatest ever shortcoming of literary theory (which also can be seen in other areas of research). Literary theory is the articulation of a theoretical framework or conceptual tool relevant for an informed appreciation of works of literature, and when such a framework or tool is deployed in a critical study of a work of literature, this process becomes literary criticism.

Scholars are not unwilling to acknowledge the eclectic nature of literary theory and criticism but will mostly rather be viewing this not really as a shortcoming but as an empowering feature that facilitates advancement of knowledge.
There is great merit in this point of view because given the space-time and epistemological limitations of the human mind, human beings can only approach issues taking off from one angle or more rather than from all angles at the same time and to the same degree as often imputed to divine minds. It is in respect of this fundamental shortcoming and the (unintentional) epistemological prejudice that goes with it that Susan Robin Suleiman for instance states that indeed all viewpoints and interpretations "tend to speak of works as if their meanings and effects were immanent; to convince someone else of the validity of one's reading, one has to claim, or at least imply, that it is the best reading, the reading most closely corresponding to the "work itself"' (192).

There exists today a wide variety of literary theories each of which evolved in response to certain historical circumstances that facilitated its emergence and which was meant to fill a gap in scholarship and social processes. And while it appears to be turning into a crowd out there, there still exists a gap which needs to be filled, one which once again is informed by social circumstances. This new literary theory will be called flipside literary theory.

However, before exploring flipside literary theory, this essay will go on to explore a number of literary theories, 
especially, Formalism, Marxism, structuralism, psychoanalysis, and feminism. This step will provide a necessary background to this first ever presentation of flipside theory and an affirmation of the gap in scholarship which exists in this respect. This is also a step that will bring to the fore the historicization and interconnectedness of all literary theories in respect of points of convergence and divergence.

\section{HISTORICIZATION OF SELECT LITERARY THEORIES}

By historicization of literary theories is meant the recognition that the emergence of a literary theory is often, if not always, facilitated by certain historical needs or circumstances, facilitated rather than determined or conditioned in the Marxist sense of those concepts. Indeed, theoretical frameworks, conceptual tools and practical approaches used within the broad background of research and scholarship are sometimes informed by real life situations. Marxism for instance, and by extension, Marxist literary theory, is one such worldview that shows a significant level of historicization since it was informed largely by the circumstances of the nineteenth century when the industrial revolution aggravated social divisions and social processes between industrialists (broadly speaking, owners of the means of production) or the bourgeoisie and workers and the poor or the proletariat. Karl Marx and Friedrich Engels actually never wrote a work dedicated to the subject of aesthetics or literary theory. Marxist literary theory is rather derived from the application of Marxist principles (such as the preponderant role of economy in social dynamics, ideology, power relations, class struggle and class conflicts, revolution, religion and its social functions, alienation, and aesthetics) to literature.

M. A. R. Habib decries a misconception subsisting in some academic quarters despite evidence to the contrary, where,

Often, the critical output of previous historical eras is implicitly treated as an inadequate and benighted prolegomenon to the dazzling insights of modern theory. The history of philosophy is sometimes seen, through the alleged lens of deconstruction, as a series of deconstructed domains: in this distorted projection, Plato, Kant, and Hegel are treated as minor thinkers, whose mistakes and blindnesses were acutely brought to the surface by major thinkers such as Derrida, Lacan, and Foucault. Only an ignorance of the history of philosophy could sanction such an attitude. The truth is that, as all of these modern thinkers recognize, far deeper contributions to philosophy were made by Kant, by Hegel, and by Marx: without these thinkers, the work of modern theorists could not have arisen and in many ways it remains frozen within the problematic defined by the earlier figures. In general, modern theory - to its credit - is less original than is often imagined (4)

As Habib notes, the twenty-seven year-long Peloponnesian War (431-404 BC) between Sparta and its allies, on the one hand, and Athens which was the leader of the Delian League, a war Athens lost, impacted Plato's life, philosophy and literary theory added to the fact that earlier in Athens during the repressive regime of the "four hundred" (411-410 $\mathrm{BC})$, the dysfunctional state of affairs included the execution of Socrates in 399 BC on allegations of impiety (15). Furthermore,

like the naturalists, Socrates and Plato distinguished between mere evidence of the senses, which was "appearance," and an underlying reality accessible only through reason (CCP, 54). Hence, Greek philosophy begins with the application of rational thinking to all areas of human life: "In the lifetime of Socrates reflection on morality and human society ceased to be the monopoly of Homer and the poets; it became another area for critical thinking" (CCP, 58). In other words, Greek philosophy begins as a challenge to the monopoly of poetry and the extension of its vision in more recent trends such as sophistic and rhetoric. Plato's opposition of philosophy to poetry effectively sets the stage for more than two thousand years of literary theory and criticism." (17)

Types of criticism in medieval times can be brought under three categories of knowledge in use at the time, that is, the medieval trivium, namely, grammatical (grammar), rhetorica (rhetoric), and dialectica (logic), which explored language and discourse in terms of interpretation and signification. However, that their boundaries were often disputed led to a situation where the late classical era made poetry a branch of rhetoric whereas the later Middle Ages placed it with grammar and the scholastics put it with logic (Habib 175). Habib also points out that, "In general, medieval literary theory gave priority to inherited forms of literature and stressed the virtue of treating traditional matter in novel ways rather than the invention of radically new viewpoints" (176). Furthermore, the humanist literary theory of the fourteenth and fifteenth centuries was informed by scholastic viewpoints with respect to "use of poetry, the place of poetry within the hierarchy of the sciences, the spiritual and moral senses of poetry, and the question of styles" (175).

According to A. J. Minnis and A. B. Scott, it was Aristotle's Physics and Metaphysics, not his Poetics, that significantly influenced scholastic literary theory. Scholastic literary theory threw light on the human qualities of authors as opposed to agency by divine inspiration (for scripture) or auctores (sources of authority which are impersonal and to be imitated) and which empowered "increasing sophistication in analyzing authorial roles (distinguishing between author, commentator, scribe, encyclopedist, etc.) and literary forms," and facilitated the development of new literary terms required "for a more comprehensive treatment of author, material, style, structure, and effect" (196).

Establishing an unbroken link between the Middle Ages and modern times, and further apart, between the ancients and the moderns, Habib notes that,

Two of the concepts central to neoclassical literary theory and practice were imitation and nature, which were intimately related. In one sense, the notion of imitation of the external world, and primarily, of human action was a reaffirmation of the ideals of objectivity and impersonality, as opposed to the increasingly sophisticated individualism and exploration of subjectivity found 
in Renaissance writers. But also integral to this notion was imitation of classical models, especially Homer and Vergil. In fact, these two aspects of imitation were often identified, as by Pope. The identification was based largely on the concept of nature. This complex concept had a number of senses. It referred to the harmonious and hierarchical order of the universe, including the various social and political hierarchies within the world. In this vast scheme of nature, everything had its proper and appointed place. The concept also referred to human nature: to what was central, timeless, and universal in human experience. Hence, "nature" had a deep moral significance, comprehending the modes of action that were permissible and excluding certain actions as "unnatural" (a term often used by Shakespeare to describe the murderous and cunning behaviour of characters such as Lady Macbeth). Clearly, the neoclassical vision of nature was very different from the meanings later given to it by the Romantics; this vision inherited something of the medieval view of nature as a providential scheme but, as will emerge shortly, it was informed by more recent scientific views of nature rather than by Aristotelian physics. The neoclassical writers generally saw the ancients such as Homer and Vergil as having already discovered and expressed the fundamental laws of nature. Hence, the external world, including the world of human action, could best be expressed by modern writers if they followed the path of imitation already paved by the ancients. Invention was of course allowed, but only as a modification of past models, not in the form of a rupture. (274)

In this background, imitation of the classics does not refer to slavish imitation but to a liberal milieu to explore one's literary creativity along lines defined by the classics, a trend seen in La Bruyère, Pope, Ben Jonson, Corneille, and Dryden who mostly acknowledged the genius of Shakespeare and Milton. In general, as neoclassicist writers tried to reinvent Aristotle's teachings about tragedy and its consequent emotions, they significantly tried to include close portrayals of human passions as part of the overriding quest to imitate nature (274).

Galin Tihanov strongly holds the position "that modern literary theory was born in the decades between the World Wars, in Eastern and Central Europe-in Russia, Bohemia, Hungary, and Poland-due to a set of intersecting cultural determinations and institutional factors" (63) and "as a response to radical changes in literature and its social relevance" (75) or "regime of relevance" (borrowed from Foucault), which means "the prevalent mode of literary consumption in a society at a particular time" and which is shaped by social and institutional factors in mutual competition and conflict (78). Tihanov maintains that "literary theory emerged in Eastern and Central Europe in the interwar decades as one of the conceptual products of the transition from a regime of relevance that recognizes literature for its role in social and political practice to a regime that values literature primarily for its qualities as an art" (78-79).

As Habib notes, while optimism that war-time chaos would soon give birth to order and beauty could be seen in William Wordsworth's poem (contained in the Prelude) about the French Revolution (1789-1799) and in a number of Romantic literary theories of that period, "Romantic literary theory has an oblique and complex, often contradictory, connection with the ideals behind - and the reality of - the Revolution" (430). In addition, Habib points out that among insights that empowered modern literary theory - especially in the area of reader-response theory - is Kant's. About the potential dilemma whereby, if aesthetic judgment is subjective and merely expresses personal feelings of pleasure rather than say something about the object being perceived, for Kant, when our judgment of an object's beauty is disinterested, it points out that there is "a ground of pleasure for all people" which "doesn't rest on any subjective inclination or private conditions" (369).

In an interesting essay, "Evolution and Literary Theory," Joseph Carroll situates literature and literary theory within the broader field of evolutionary theory and establishes a link between literature and science on the premise that literary criticism combines elements from the humanities and science. This provides the understanding that dynamics in scholarship in the field of literature can never be rightly conceived as unfurling in isolation but as interconnected with social reality in some important respects.

Terry Eagleton in turn underscores the point that research perspectives to social reality neither emerge nor exist in isolation but are interconnected with others and that known literary theories are not just simply concerned with literary works but have implications beyond literature (Literary Theory vii). As Tihanov goes on to state, "I submit that modern literary theory was born in the decades between the World Wars, in Eastern and Central Europe - in Russia, Bohemia, Hungary, and Poland - due to a set of intersecting cultural determinations and institutional factors" (63).

It has to be acknowledged that particularly with the rise of the Russian Formalists shortly before the 1917 Bolshevik revolution and their massive state suppression during the Stalinist era, literary theories can now be generally divided into three categories, namely, theories from a sociological point of view or cultural studies such as Marxism, feminism, postcolonialism, New Historicism, and Queer theory; theories from a literary point of view or literariness such as Formalism, Structuralism, post-Structuralism, and New Criticism; and lastly, theories from an interactive point of view such as reader-response. In other words, while the one views literature from the important point of its relevance to social processes, the other views it from the important point of its status as a subsistent entity, a world of its own, "art for art's sake" (l'art pour l'art) in the words of Formalists, and yet another views it from the important point of hermeneutic interactions between text and person.

This three-fold categorization might immediately suggest that literary theories that immediately honour literature chiefly as a subsistent entity deserving every respect given to a freeborn in contradiction from someone (a text) at the service of, indentured or enslaved to another - as implied by sociological and interactive literary theories - must rank higher than these other theories. This is because a literary 
theory is by implication, firstly, a theory of what makes a text (whether written or oral) literary, and only secondly about what services the text renders. In a sense, all texts are freeborn or should be, until made to serve some interests.

While for Galin Tihanov, literary theory is already in decline as a distinct field of study particularly since the twenty-first century after its beginnings in the 1910s when it was dominated by the Russian Formalists (61), a great amount of work continues to be done in this field, which, among other things, continues to preserve that essential link between literature and social dynamics. As Tihanov also notes, while literary studies increasingly sought emancipation from philosophy - which was, in earlier times, a monolithic field between the 1970s and 1980s especially under the influence of Derridean deconstruction, literary theory today appears to be leaning towards reuniting with philosophy in ways that have begun to make the once clear distinctions stressed by Formalists between literary and non-literary texts to disappear (62).

Terry Eagleton points out that for Roman Jakobson, literature is writing that represents an "organized violence committed on ordinary speech" (qtd. in Eagleton, Literary Theo$r y$ 2). Furthermore, armed with this viewpoint, Jakobson and another very important Russian Formalist, Viktor Shklovsky, but also Osip Brik, Yury Tynyanov, Boris Eichenbaum and Boris Tomashevsky who inaugurated Formalism in the early $20^{\text {th }}$ century effectively turned the attention of literary criticism from sociological, psychological and hermeneutic concerns to the structure of language used in literary writing. For them, language is to be studied as an end rather than as a means or conduits for something else. In this sense, Formalist literary criticism focuses on the form of linguistic expression in literature rather than on the content and considers literary devices (imagery, metre, rhyme, narrative technique, etc.) as transforming language beyond its commonplace use, that is, making language unfamiliar, which is the basis of the "defamiliarization" or "estrangement" thesis for which Russian Formalism is popular (Literary Theory 2-3).

Sadly, as sometimes happens to agents and world visions that are ahead of their time, Russian Formalists suffered great persecutions by Bolshevik regimes from the 1930s and a number of them were forced out of communist territories. It came to a point when Lenin's Bolshevik Party Central Committee issued a decree in 1928 that all literature must serve party interests. The Stalinist era recorded massive suppression of all literary creativity not tailored towards party interests.

In M. A. R. Habib's view, "The history of literary criticism is profoundly imbricated in the history of thought in a broad range of spheres, philosophical, religious, social, economic, and psychological.... [and situates] modern literary theory within a historically broader context, to view it from a perspective that might evince its connections and lines of origin, descent, and reaction" (3). Nevertheless, this understanding contrasts sharply with Tihanov's assumption that "the early 1990s represent the last stage in the protracted demise of literary theory as an autonomous branch of the humanities. The abandonment of literary theory in favour of projects in semiotics as a form of cultural theory (Lot- man), and in favour of forays into philosophical anthropology (Iser), were symptoms of ill health and of a decline in self-sufficiency" (63).

Tihanov goes on to historicize and highlight how literary theories, among which Russian Formalism occupies a significant position, connect with each other while they deploy their apparently different world visions to explore concerns that interest them. For him,

advances in literary theory in its second 'golden age,' the 1960s and 1970s, were hardly more than elaborations and variations on themes, problems, and solutions played out in the interwar period in Central and Eastern Europe. French structuralism, however refined (and sometimes reluctant to acknowledge its predecessors), was of course made possible by the work of Ferdinand de Saussure. But structuralism also depended on the achievements of Russian Formalism and the Prague Linguistic Circle, as well as on the formulation of the principles of phonology by Nikolai Trubetskoi and Roman Jakobson in the 1930s. Narratology - notwithstanding the differences discernible in its later versions (those of Claude Lévi-Strauss, Algirdas J. Greimas, Claude Bremond, Gérard Genette, Eberhard Lämmert, Dorrit Cohn, Mieke Bal) — never quite severed itself from the legacy of Vladimir Propp, whose Morphology of the Folktale appeared as early as 1928. The continental version of reception theory in the 1970s was anticipated in works of the Prague Circle, above all those of Felix Vodička, who borrowed somewhat freely from Ingarden. Finally, Marxist literary theory in its later heyday was deeply influenced by the work of Georg Lukács in the 1930s. (64) Other important contributors to Marxist cultural and literary theory include Louis Althusser, Lucien Goldmann, and Pierre Macherey who all moved away from Hegel and were heavily influenced by structuralism in the earlier twentieth century, "which stressed the role of larger signifying systems and institutional structures over individual agency and intention" (543).

As Tihanov (65) also notes, although hermeneutics failed to develop into a literary theory during the 1920s and 1930s, since World War I, transformations in philosophical paradigms and a growing inclination to apply them to literature facilitated the birth of modern literary theory. Such philosophical transformations that became relevant to literary criticism include Georg Lukács' reformulation of Marxism in the 1920s and 1930s, and Roman Ingarden's reformulation of Husserlian phenomenology. These significant contributions, however, were unlike collective contributions from the Russian Formalists and the Prague Circle in the 1920s and 1930s, which "reflected a growing discontent with scholarly positivism, as well as - most crucially — a need to confront, make sense of, and give support to fresh and radical modes of creative writing... Thinking about literature, in other words, altered radically in the earlier twentieth century because of changes... in literature itself, and changes in. continental philosophy" (66).

As Tihanov points out, while Shklovsky had to criticize Eikhenbaum when the latter abandoned Formalism for 
sociology of literature (67) and Lukács for the implications of his reformulation of Marxism for literature, as did Bakhtin too (73), Roman Jakobson and Jan Mukařovský criticized Ferdinand de Saussure especially for his opposition between synchrony and diachrony (75). While Saussure is known, among other things, for the impact of his theory of the arbitrariness of language on modern literary theory, Habib (491) points out that even Arthur Symons "stated that language itself is 'arbitrary': words and symbols are 'mere sounds of the voice to which we have agreed to give certain significations.' Such arbitrariness is only legitimized when 'it has obtained the force of a convention" (qtd. in Habib 491). For Habib, French symbolism looks like "a return to the arbitrariness beneath the layers of convention" and "must erect subjectivity itself - and the literature which uniquely expresses it - into a religion. As Symons says, such literature attains its 'authentic speech' only by accepting a heavier burden: 'it becomes itself a kind of religion"” (qtd. in Habib 491).

In the 1950s and 1970s after World War II, similar historicized unfolding of factors led to the shifting of the centre of theory towards France and Francophone theorists, which included Lucien Goldmann, Algirdas Greimas, Tzvetan Todorov, and Julia Kristeva who made significant contributions to semiotics, narratology, struc turalism, poststructuralism, Marxist literary theory, psychoanalysis, and feminism (Tihanov 69). Tihanov constitutes significant aspects of the activities of the Russian Formalism and the Prague Circle such as Yuri Tynianov's “On Literary Evolution” and Boris Eikhenbaum's "Literature and the Literary Everyday" as part of broader social dynamics towards constructing a new political reality (a state) and empowering national consciousness (66).

In addition, in relation to the rise of modern literary theory, for Tihanov, the "possibility of 'estranging' the sanctity and naturalness of one's own literature by analyzing it in another language or by refracting it through the prism of another culture seems to be of paramount significance for the emergence of modern literary theory." (70). Here, Tihanov includes Fritz Mauthner's acknowledgment in his memoirs that his later interest in the psychology and philosophy of language was connected to the condition of polyglossia in pre-World War I era Prague (70).

Interest in language studies led up to the emergence of structuralism, which basically sees a work of literature as a unified system of linguistic meanings and proceeds to closely analyze each component (or component "structure") and its functioning in relation to others components. Structuralism was provided from Ferdinand de Saussure's lecture notes entitled "Course in General Linguistics" which were published posthumously by his students. R. Harris (ix) and many scholars consider Saussure the father of structural linguistics while critics like Roland Barthes, F. Jameson, J. Culler, Terence Hawkes, and Terry Eagleton describe linguistics as the foundation of modern structuralism.

One of Saussure's core propositions is that, "A language is a system in which all the elements fit together, and in which the value of any one element depends on the simultaneous coexistence of all the others" (113). Saussure's inge- nuity lies in his application of the concept of structure to linguistics. More broadly and from a historicized perspective, the concept of structure, according to G. Radford and M. Radford, was borrowed from architecture and construction to biology, geology and mathematics in the $17^{\text {th }}$ and $18^{\text {th }}$ centuries and finally to linguistics and the social sciences in the $20^{\text {th }}$ century $(60)$.

In this regard, Jean Piaget describes structure as an arrangement of linguistic entities in a way that embodies the idea of wholeness, the idea of transformation and the idea of self-regulation (qtd. in Taghizadeh 286). "Wholeness," as Terence Hawkes explains, refers to internal coherence whereby constituent parts of a whole

conform to a set of intrinsic laws which determine its nature and theirs. These laws confer on the constituent parts within the structure overall properties larger than those each individually possesses outside it. Thus a structure is quite different from an aggregate: its constituent parts have no genuinely independent existence outside the structure in the same form that they have within it. (5)

A structure is also transformational, that is, it is a structuring, rather than passive or static since "language, a basic human structure, is capable of transforming various fundamental sentences into the widest variety of new utterances while retaining these within its own particular structure" (Hawkes 6). Furthermore, structure is self-regulating since it seals off the system from reference to other systems "and makes no appeals beyond itself in order to validate its transformational procedures" (6). As Hawkes adds, the word "dog" exists and functions without reference to any barking four-legged creature existing in the real world; its behaviour is instead determined just by its status as a noun within a linguistic expression (6).

Another great contribution from Ferdinand de Saussure is his distinction between langue and parole, whereby, langue is the structure or system of language which exists in the minds of the members of a language community whereas parole is actual speech utterances made by each individual member and about which each member is capable of generating countless instances of utterances all of which are subject to the existing laws or structure of that language system (langue). In addition, as Ali Taghizadeh puts it,

The works of Saussure and Russian formalists of the early twentieth century grounded the structuralist thought in its modern application. From the eye of the formalists, words in poetry did not function as signifiers only, for they were signifieds also. Formalists defined literature as a functional system, as a set of devices whose value was determined by other devices which are played off against them (those of other genres, past styles, etc.). For these avant-garde structuralists, a literary work presupposed other works, genres, styles, and structures of meaning which go beyond the work itself. And they regarded literature a kind of langue of which each specific work was an instance of parole" (286).

However, granted the implications of structuralism for modern literary theory, Ali Taghizadeh locates its ear- 
liest roots in ancient times and traces it onwards from Plato (428/427 BC-348/347 BC) and Aristotle (384 $\mathrm{BC}-322 \mathrm{BC})$ through the Middle Ages $\left(5^{\text {th }}-15^{\text {th }}\right.$ cent.), the Renaissance $\left(14^{\text {th }}-17^{\text {th }}\right.$ cent. $)$, Romanticism $\left(18^{\text {th }}\right.$ $19^{\text {th }}$ cent. $)$, the Victorian era $\left(19^{\text {th }}-20^{\text {th }}\right.$ cent.) to modern times $\left(20^{\text {th }}\right.$ cent. -$)$. In Taghizadeh's view, early or pre$20^{\text {th }}$ century structuralism was:

the sum total of what would make the external form and organization of a literary work, as well as the interests and curiosities of teachers and students of literature. In this sense, structure was perhaps mainly an external aspect of poetry rather than an internal feature of it. The questions about the genre or type of a certain poem, about its metrical patterns, and about its rhyme scheme were handled for structure. (286)

In respect of the historical circumstances of the emergence of structuralism as a literary theory, Ibrahim Chinade Sanusi (125) opines that structuralism emerged at a time when criticism was in a confused state and guided by subjective rather than objective value judgments, a state of affairs that underscored a need to systematize the process and build criticism on objective laws. In this wise, in Saussure's view, the underlying systems of conventions should be the object of study for linguistics. Saussure further sees language as a system of signs; that the sign is the basic unit of meaning; and the sign comprises a signifier and a signified (the mental 'concept')... the sign is arbitrary. Therefore, the relation between the signifier and the signified is only a matter of convention. This distinction, for Saussure, does not refer to a name or a thing but to that between word image and the concept, which can only be separable at the analytical level. [For him] "if words stood for pre-existing entities they would all have exact equivalents in meaning from one language to the next, but all this is not true" (Sanusi 126)

Structuralism's systematic approach and competitive allure projected it in the background of the perceived weaknesses of other literary theories in modern times. In contrast with such other theories,

When applied to literature, structuralism becomes radical and increasingly irreducible. The $20^{\text {th }}$-century literary criticism rejects the view that regards literature as a means of communication between the author and the reader. It is in sharp opposition with the $19^{\text {th }}$-century theories of language that were mimetic and expressive. A proper study of literature is not, structuralists say, a close reading on the separated literary texts, but is an inquiry on the conditions that are influential on the act of interpretation. So, structuralists often investigate the system whereby individual texts are related to each other, because they believe that they are only expressing agents of a superior social and cultural system. From their point of view, the primary task of the critic is to study the "grammar" of literature, the system of rules that govern literary interpretation. Thus, they often search for the common understructures of literary productions of a certain author or even a whole period. (Taghizadeh 288)
Accomplishments of structuralist can be seen in the narratologies of Vladimir Propp and Tzvetan Todorov who see the meaning of a story as developing from its overall structure (langue) rather than from the isolated themes of each story, and Claude Levi-Strauss' structural exploration of the language of myths. For Strauss, as Taghizadeh notes,

myth is structured like language, and every myth is therefore an example of parole... [and] the recurrent themes that run through all of them. he named mythemes. As the building block of a myth, a mytheme takes the same role in it as a phoneme takes in language. Such a nodal object finds meaning only within a mythic structure. This means that the meaning of a myth depends both on the structure of the myth and the distribution of mythemes within the story. Therefore, the meaning of a myth originates from this structural pattern which we unconsciously master. (288)

Yet, structuralism too has some weaknesses, and as Sanusi points out, this includes the disturbing penchant of its founding fathers for neologisms as well as the fact that "[I]nternal squabbling at the University of Cambridge over structuralism did little to enhance the public image of criticism particularly during the short period the media interested itself in this hitherto unknown phenomenon. It failed to find a single academic who could explain the theory satisfactorily to the ordinary reader" (125-126).

G. Radford and M. Radford contrast structuralism with the critical program of post-structuralism by pointing out that,

while structuralism posits that the language system can be described in an objective and scientific manner, post-structuralism suggests that such descriptions are themselves always highly contextual. Whereas de Saussure's structuralism was confident that the principles by which language is organized can be fully determined and described, post-structuralism calls into question all such assumptions and suggests that all such conclusions are always fragile and open to subversion. (61)

Furthermore, with respect to another point of contrast which shows another weakness on the side of structuralism, G. Radford and M. Radford remark that Saussure "focused almost exclusively on the general rules and codes of the language system which all of users must share if it is to be used as a means of communication. He gave little or no attention to how this system could serve the purpose of reference, i.e., how signs refer to the world of things, people, and events outside language" (67). This shortcoming, according to them, led to the emergence of post-structuralist literary theory.

An approach quite different from structuralism, post-structuralism and other literary theories already explored can be seen in psychoanalytic literary theory. Psychoanalytic literary theory, which is derived mostly from the work of Sigmund Freud but also Jacques Lacan, is an interesting contribution to modern theory and requires an understanding of the core insights of psychoanalysis.

Psychoanalysis, a method of investigating unconscious mental processes and their impacts on visible human be- 
haviour (particularly, neurosis), is a field in psychology developed by Sigmund Freud. Psychotherapy is the application of psychoanalytic theory to the treatment of mental illnesses (psychiatry), especially, cases with symptoms such as paralyzed limbs, numbness, amnesia, tics, tremors, and fainting or loss of consciousness.

In the course of their investigation and treatment of hysteria, these symptoms, which were for the first time labeled "neurotic" by Sigmund Freud and Jean Charcot under whom he was studying neurology and hypnosis since they considered them neurological conditions, later became collectively known as "neuroses." However, Freud came to the conclusion that there were portions of the mind hypnosis was not accessing and thereafter, independently developed his theory of psychoanalysis which is based on the alleged conflict between unconscious and conscious regions of the min and the method of "free association" ("talking cure") by which patients, usually relaxing on couches, spoke freely whatever came to their minds, which for Freud provided a path to their unconscious.

Freud's The Psychopathology of Everyday Life provides the view that slips of speech ("parapraxes" or "Freudian slips") reveal unconscious inordinate wishes while his Jokes and their Relation to the Unconscious argues that jokes are transformations of unacceptable aggressive or libidinal impulses in acceptably comic forms. Freud's The Interpretation of Dreams posits that the mind consists of a series of layers with the conscious region being at the top and repressed memories and crude drives being at deeper levels of unavailability to conscious thought. He likened this topographical model to an iceberg whereby, what we are aware of is only a tip (one-fifth) of the iceberg whereas most of it (four-fifths) lie hidden. In his view, dreams provide a path to the hidden self if carefully interpreted. During dreams (whose events are usually not logical), unacceptable impulses and thoughts, which he calls the "latent dream content," are transformed into a conscious form called the "manifest dream," which is, however, no longer immediately comprehensible. Freud explains "dream work" as the process by which latent dream is transformed into manifest dream. A stage during this process, called "secondary revision," refers to the mind editing a dream to make it a relatively consistent and comprehensible narrative.

The unconscious refers to that region of the human mind (psyche) where thoughts could be realized in the form of images rather than concepts, thoughts and feelings initially correlated could be displaced or moved outside their contexts, some objects could be represented symbolically by means of other objects, and disparate images or ideas could be conflated. Crucial to these mental processes is the absence of logic in its operation unlike conscious mental processes to which the laws of logic are indispensable.

Adult sexuality is a developmental process originating from infantile sexuality and evolving across three erotogenic zones or manners of bodily expressions of the libido - these stages sometimes overlap, - namely, the oral, anal, and genital, and which correspond to specific patterns of behaviour in the relationship between a child and its parents or adults. At the phallic stage (when the erotogenic zone is the genitals), while the female child realizes she has no penis and thenceforth experiences penis envy, the male child realizes a girl has no penis and thenceforth experiences castration anxiety. In this psychosocial context, the phallus (not literarily penis) becomes a standard or a symbol of (male) domination or elitism. A critical period is the Oedipal period, which occurs between ages four to six because this is when the child for the first time becomes capable of emotional attachment to the parent of the opposite sex and reacts like a rival to the parent of the same sex. Physical and cognitive immaturity impair the child's efforts against its fantasized competition and success in human or love relationships later in life will depend on how effectively the child overcomes these early emotional attachment, fears and inner crisis and how parents respond to the child's distortions of reality.

Freud's psychoanalytic theory talks so much about the id, the ego, and the superego as the three broad divisions of interrelational operations between the mind and the body. The id refers to the crude sexual and aggressive drive (triebe) arising innately from the body which demands immediate satisfaction and feels pleasurable. Thus, the id is dominated by the pleasure principle. However, in his later works, Freud leaned more towards a psychological rather than biological conceptualization of drives.

The ego, which is the domain of functions like perception, cognition, reasoning, and motor control, refers to that psychological system tasked with providing and assessing conditions under which satisfaction or pleasure can be realized. The ego engages in reality testing and can enforce the postponement of satisfaction as situations demand as well as employ defense mechanisms (which he calls "resistance") against unacceptable impulses such as by repression (exclusion from conscious awareness), projection (ascribing one's inclinations to others), and reaction formation (developing a behaviour pattern opposed to a strong unconscious need). Anxiety when confronted by unwanted impulses triggers defense mechanisms. Anxiety derives from felt danger situations such as fear of abandonment by or loss of a loved one (the object), risk of losing a beloved's love, danger of retaliation and punishment, and, finally, hazard of reproach by the superego.

The ego is tasked with mediating between the id, the superego, and the external world. The more the ego is impaired from effectively carrying out this task between these conflicting forces due to the ego's development being still hampered by its unresolved childhood conflicts called fixations or complexes, or the more it suffers regression (reverting to earlier satisfactions or crude functionings), the greater the likelihood that the individual will veer into symptom formation (whereby inner conflicts manifest as neurotic symptoms) as the ego's last ditch effort to maintain some semblance of control and integrity. Symptom formation, character and impulse disorders, perversions and sublimations are compromise processes or adaptive methods deployed by the ego as a result of unresolved or irresolvable conflicts in the mind.

The superego refers to that psycho-ethical system imposed first by parents, then, by society, which check the inclinations of an individual as well as serve as a value system to judge actions and thoughts, hence, generating feelings of 
guilt or shame as the case may be. It also includes temporary postponement of satisfaction. The superego has power like a drive, is partly unconscious, and can generate feelings of guilt not grounded in any conscious transgression.

Major disciples of psychoanalysis who have made their own significant contributions and provided new perspectives or reformulations include Carl Jung, Alfred Adler, Otto Rank, and Melanie Klein. Harold Bloom makes the interesting contribution of interpreting all literary history in terms of the Oedipal conflict whereby new or relatively unknown poets are considered locked in an unconscious battle to dethrone and replace (hence, "castrate") their counterparts who have made it to the top (Eagleton, Literary Theory 159) and whose success feels like a phallic castration to them. It is also significant that a link between Marxist thought and Freudian psychoanalysis can be found for instance in Freud's Introductory Lectures on Psychoanalysis where he states that, "The motive of human society is in the last resort an economic one" (Eagleton, Literary Theory 131).

In addition, Freud's concept of Oedipal conflict was, of course, borrowed from the Sophoclean play, Oedipus rex, to which a number of literary works, Ola Rotimi's The Gods are not to Blame for instance, have an intertextual relationship across a trope which may be described as: "Kill your father, marry your mother, suffer afflictions." In defense of the intertextual merits of such works, Anthony N. Akwanya rightly states that, "The Gods are not to Blame is undoubtedly a self-contained work, having put together a set of incidents, bits and pieces of myths, including the Sophoclean Oedipus myth, the Ogun and Ifa myths together with agricultural and tribal practices to build a new totality" (255).

As Terry Eagleton (Literary Theory 155) notes, psychoanalytical literary criticism comes in four broad kinds according to areas of interest about a literary work: the author (author's life, social context and authorial intention), the contents (exploring the unconscious motivations of characters or psychoanalytical significance of objects or events), its informal construction (investigating the process of writing), and the reader (sociological factors surrounding a reader). In addition, while most psychoanalytical criticism has been about the author and content of a work, psychoanalysing the author is a speculative business and faces a huge number of problems.

For instance, asking what base factors or unconscious processes were behind a poet's titling of a poem, a poetry collection or the contents of poems throws the critic or reader into an uncharted territory that can only be navigated by speculative reasoning. In the event of the physical unavailability of the author, the critic can never be able to bring him or her for a session in psychoanalytic investigation and even when available, the question arises as to how qualified the critic or reader might be to undertake such a program? In contradistinction, answers to questions about content, construction and readers can be more easily provided.

As Eagleton (Literary Theory 156) points out, Freud is known to have compared art to neurosis whereby, the artist, like a neurotic, is under the influence of very powerful inner drives which make him turn away from reality to fantasy but unlike the neurotic, he or she could effectively harness those inner forces to produce something aesthetic as a work of literature. This also brings to light the indispensable role of artistic form, that is, literary devices and techniques, which are tools the artist deploys to harness unacceptable impulses and produce a literary work in publicly acceptable forms. This also dovetails with the Freudian concept of secondary revision by which means the mind retouches a dream to put it in a form acceptable by public standards. Furthermore, it offers the view that literary art is a form of production.

All this constitute psychoanalytic literary theory, that is, the investigation of literary works to uncover their treatments of inner personal conflicts, inner family conflicts, matters connected with sexuality, dreams, parapraxes and the impacts of all these on social processes. It is also interesting that Freud conceded he never understood women sufficiently - he once called female sexuality the "dark continent" (qtd. in Eagleton, Marxism and Literary Criticism 135) - and his treatment of them in some of his writings show some bias.

Feminist literary theory is one that critically investigates works of literature to uncover their treatments of female characters and to question them in relation to feminism's overriding concerns about the interests of women in society, the biological determination of (the female) sex, the cultural articulation of gender, roles and opportunities in family and society. It also takes into consideration the fact that in recent times, feminism has broadened its scope and multitasks on (anti-)patriarchy discourse, women liberation and self-affirmation, equal rights and equal pay, abortion rights, the LGBTQIA (lesbian, gay, bisexual, transgender, queer, intersex, asexual) movement (which now includes official "gender fluid" designations as well as some yet-to-be-coined "identities"), divorce and single parenting, and so much more, including liberal versus conservative politics. Internal disagreements among feminists - which might be between individual feminists or between feminists from different groups, races, religious or socio-cultural backgrounds - on what positions to take on some core issues have paved the way for many critics to consider feminism a shape-shifting social movement with self-conflicting agenda.

Feminism as both a personal consciousness and a social movement is open to both men and women. In this wise, Owen Fiss points out that "Feminism is the set of beliefs and ideas that belong to the broad social and political movement to achieve greater equality for women. As its governing ideology, feminism gives shape and direction to the women's movement and, of course, is shaped by it" (413). However, the rise of non-Western versions of feminism - which rise largely in protest - both enriches and confuses the mix.

Though the exact origins of the words "feminism" and "feminist" are difficult to ascertain, the former is considered a neologism introduced by Charles Fourier in 1837 in France just as both words are believed to have come into use in Europe in the late $19^{\text {th }}$ century (in France and the Netherlands in 1872, in Great Britain in the 1890s while the Oxford English Dictionary dates "feminist" at 1894 and "feminism" at 1895) and in the United States in 1910. 
However, it is arguable that feminist consciousness and practical reactions to patriarchy have always existed in some forms across the cultures of the world. Patriarchy, according to David Makaliu, "is the social system in which the role of the male is the primary and the locus of social structure, makes objects of women as property to be possessed, for the economic, sexual and social stability of the man" (qtd. in Ogwude 278). Nevertheless, as an increasingly systematized and globe-spreading consciousness and practices assisted by modern means of communication, feminism is credited to the West.

While some critics talk about a period of "proto-feminism" before and during the Medieval period, mainline feminist literary theory (and feminism) is said to have emerged after World War II and has influenced intellectual circles in America particularly in the 1960s. There have been great strides since then, such as the Frankfurt School's critical theory which considered gender in the terms of Freudian and Lacanian psychoanalysis and constituted it within the deconstruction of existing relations of power in society. Notable feminist writers of the Western tradition include S. Dalton, Bressler, Gill Plain, Susan Sellers, George Eliot and Margaret Fuller but the most influential writers include Elizabeth Johnson, Simone de Beauvoir, Jane Austen, and Virginia Woolf.

On a general note, the history of feminism has been divided into the First, Second, and Third Waves, with perceived failures in one Wave giving rise to another Wave. The First Wave emerged in the $19^{\text {th }}$ and early $20^{\text {th }}$ centuries in the United Kingdom and the United States and promoted equal contract, property rights, marriage and parenting responsibilities. Before then, there were two works by Mary Wollstonecraft, namely, A Vindication of the Rights of Women (1792) in which she questioned inequalities between men and women, and an unfinished work, Mariah, or the Wrongs of Women in which she highlighted female sexuality. Some $19^{\text {th }}$ century female writers had to write under pseudonyms Mary Ann Evans, for instance, wrote as "George Eliot" - so they can get fair rather than biased criticisms of their works. By the end of the $19^{\text {th }}$ century, First Wave feminism came to focus more on the politics of women suffrage and ended with the passage of the Nineteenth Amendment of the United States constitution in 1919. In the United States, feminist consciousness was heavily influenced by Quaker theology which affirmed equality of men and women before God.

Feminist literary theory and feminism found broader exploration in works of literature during the Second Wave particularly in the 1960s and 1970s during the Civil Rights movement in the United States and Europe and similar movements in other regions such as in parts of Asia and the Arab world. It was more about the legal and social equality of men and women. This included economic choices in relation to letting women go after any career of their choice, and biological choices in respect of matters of motherhood, childbirth and abortion. In the 1970s, Elaine Showalter introduced the concept of gynocriticism (gynocritics) which was meant to construct a female conceptual framework for the analysis of works by women writers. Furthermore, the Unit- ed Nations stepped in and has so far organized four world conferences on women which are characterized by a global agenda for gender equality and women empowerment, namely, Mexico City (1975), Copenhagen (1980), Nairobi (1985), and Beijing (1995) followed by 5-year reviews.

As Owen Fiss notes, two epoch-making Supreme Court judgments in the constitutional law of the United States heightened feminist activism. Firstly, Griswold v. Connecticut [381 U.S. 479 (1965)] "established a constitutional right to privacy and protected access to birth control" while secondly, Roe v. Wade [410 U.S. 113 (1973)] "built on Griswold to set aside laws criminalizing abortion" (414). Second Wave feminism also sought to overthrow patriarchy and was assisted by a variety of writings in law. It is significant to note, however, that the woman pseudo-named "Roe" in Roe v. Wade, that is, Norma L. McCorvey, who went to court seeking freedom to abort and actually won the case, later in life repudiated abortion and became a pro-life activist. However, this did not imply that the law which bears her name will suddenly end.

Third Wave feminism arose in the early 1990s to present a more challenging critique of both patriarchy and those definitions of feminity that take their bearings from the experiences of upper-middle class white women. Third Wave feminism also celebrates sexuality as a means of female empowerment and called for acceptance of what can be called the modern gender rainbow, that is, LGBTQIA, "gender fluid" and some other yet-to-be-coined official "identities." For instance, a Canadian woman living in British Columbia, Kori Doty, who identifies as "gender neutral" partnered with a "Gender Free I.D Coalition" group to get the Canadian government to accept her decision that binary male-female gender information should be excluded from the birth certificate of her baby, Searly Alti who was born in November 2016. Her claim was that when the child grows up, it can decide what gender to identify with. The government predictably acquiesced under pressure and issued a birth certificate in April 2017 with a non-binary "U" ("unspecified" or "unknown") gender for the child, the first of its kind.

Third Wave feminism also highlights ongoing internal debates between those feminists who assert there are inherent differences between the sexes and those who rather argue that both are the same and consider gender roles as mere social constructs. In addition, whereas the First and Second Wave feminisms apply to West, many critics hoist African or black feminism high among Third Wave feminism. The first widely known African feminist writer is Flora Nwapa who wrote Efuru, Idu, One is Enough, and Women are Different. Other accomplished writers include Buchi Emecheta, Mariama Bâ, and Nawal el Saadawi. However, low literacy rate in Africa is among African feminism's setbacks and which seems to limit its influence to middle-class and upper class educated women and men.

Granted there are continuities in these three feminisms, Gwendolyn Mikell still maintains that,

African feminism owes its origin to different dynamics than those that generated Western feminism. It has largely been shaped by African women's resistance 
to Western hegemony and its legacy within African culture.it does not grow out of bourgeois individualism and the patriarchal control over women within capitalistic industrializing societies... The debates in many Western countries about essentialism, the female body, and radical feminism are not characteristic of the new African feminism. Rather the slowly emerging African feminism is distinctively heterosexual, pro-natal and concerned with many "bread, butter, culture, and power" issues. (4)

The need to differentiate African feminism from its Western counterpart is grounded on the fact that the life stories of African women in history is different in many important respects from that of Western women even though certain experiences are common to all. One sore point of distinction is the centuries of dehumanizing experiences African women suffered in the hands of white men and women during the transatlantic slave trade and the colonial era. In this regard, there is also a growing rejection of the label, "Third Wave feminism," because of its racist undertones, and a strong demand by many Diaspora African feminists for a separate identity from their Western counterparts. In addition, African feminism is considered by some critics to have emerged from the collective structures of African society whereas Western feminism evolved from middle class individualism and rebellion against patriarchy.

While the debate rages as to whether African feminism is a mere offshoot of Western feminism or rather mostly emerged independently, it is also debated whether to call it "African feminism" or "African womanism," for which reason Naomi Nkealah provides an even longer list: "womanism," "stiwanism," "motherism," "femalism," "nego-feminism" ("negro-feminism") and "snail-sense feminism." Grounds for this includes the point that African feminism deals with women first and foremost as human beings with men rather than as sexual beings constituted (in conflict) with the male. Furthermore, many Africans differ in opinion with Westerners on volatile issues such as abortion, divorce, single parenthood, prostitution, human trafficking, child labour, genital mutilation, polygamy, open relationships, the LGBTQIA movement, responses to "gender fluid" and yetto-be-coined "identities."

Queer literary theory (or gender studies), which increasingly accrues some political clout, evolved from the modern consciousness and responses towards variant gender descriptions or identities beyond the male-female binary. It explores works of literature in search of depictions of concerns associated with the LGBTQIA (lesbian, gay, bisexual, transgender, queer, intersex, asexual) movement and responses towards "gender fluid" and other yet-to-be-coined "identities." Queer literary theory explores all this in relation to social dynamics and questions socio-cultural assumptions of normality and deviance or perversion, and assumptions and attitudes towards the cisgender-transgender divide.

While New Criticism views a text as a self-contained entity independent of its author (as with Roland Barthes' "death of the author"), its reader, and their historical circumstances and rather focuses attention on literary devices and techniques deployed in it, New Historicism emphasizes the importance of a broader reading of a text by inclusion of the socio-historical circumstances surrounding its authorship and readership in the evaluation of its aesthetic merits. Postcolonial literary theory investigates literary works for frameworks of imperialism or colonialism and the impact of all that on the lives of subaltern people seeing as colonialism continues now in the form of neocolonialism. Reader-response criticism, on the contrary, focuses attention on how a reader appreciates a work of literature and justifies the subjective valuation of texts rather than concede the existence of objective frameworks. In addition, it empowers readers to create meanings out of what they read and to consider them absolute in contradistinction from discovering meanings allegedly already constituted in them by their authors.

In a general conclusion, literary theory has come a long way and has accomplished a lot in the various forms it has been articulated and under certain historical circumstances from ancient to modern times. While literary theories can be generally divided into theories from sociological perspectives and those from linguistic (literariness) perspectives, a number of them having already being explored, there is no existing literary theory that is laser-focused on victims of social existence (this term will be explained in subsequent sections). It is this gap in scholarship that flipside theory has emerged to fill.

\section{FLIPSIDE LITERARY THEORY}

To cut to the chase, flipside refers to the other side of the coin, that unseen, not-easily-seen or ignored side which, on the contrary, in equal measure constitutes with the seen or acclaimed side the total reality of the coin. This flipside of society or flipside society are victims of social existence who mainstream society or flipview society, intentionally or inadvertently ignores and undermines, and which at different levels and different ways upsets or disrupts social processes and puts a lot of things at risk. Put another way, it is a lot safer when an aircraft is flying on two engines than on one. In addition, reality is not one sided; half of it lies flipside.

Victims of social existence are people who simply for reasons of where and when they were born or where they reside and a number of other unforeseen circumstances hardly within their control have been pushed to the margins of society and exploited even there. These are people who are trampled upon, undermined or insufficiently catered for by mainstream society or by the elite such as roadside beggars, dumpster scavengers, petty traders, children hawking wares at traffic jams, homeless people, other categories of less privileged people such as refugees, migrants, contrite prisoners and people wrongly accused and punished. To think that it is widely assumed that everyone is concerned about the plight of these people!

Yet, there exists no single literary theory that is laser-focused on or solely investigates depictions of the psycho-social conditions and aspirations of victims of social existence in works of literature contrary to how feminist literary theory has emerged to chiefly investigate depictions of women and matters related to sex and gender in works of literature while 
Marxist literary theory continues to investigate circumstances of the proletariat and matters of ideology, class struggle and class conflict and a number of other concerns found especially in a capitalist society. It is important to note that the purview of the concept of flipside society or victims of social existence includes major aspects of but extends well beyond the purviews of Marxism and feminism.

It is this lack in the global tool kit of literary theories that flipside literary theory has come to fill. It is new not in the sense of being the first ever literary theory to call attention to the plight of the poor, marginalized and exploited people of society but because it makes this its sole concern unlike some other literary theories that multitask on many agenda. Flipside theory meaningfully and effectively brings discourse concerning victims of social existence to the fore where it rightly belongs and establishes that both flipview society and flipside society deserve equal treatment rather than constitute flipside society the forgotten or irrelevant humanity, courted and appeased particularly only when elections are around the corner or to win public admiration. Indeed, reality is not one-sided; half of it lies flipside of life.

To historicize the emergence of flipside theory, its emergence is facilitated chiefly by the circumstances of a world where world leaders and the elite of societies around the world posture in public that they are all for better life conditions for disadvantaged populations living around them but hardly do enough to make this a reality. While some recent researchers sometimes try to force statistics to provide somewhat optimistic results about levels of poverty around the world for instance, not too long ago in 2013, the World Bank published a report which says about 1 in 10 people $(10.7 \%$ of world's population or 767 million people) live below the poverty line, which is pegged at $\$ 1.90$ per day and that half of the people in extreme poverty globally are in Sub-Saharan Africa. While DoSomething.org provides from analyzed data that over 3 billion people (nearly $1 / 2$ of world's population) currently live on less than $\$ 2.50$ per day, Oxfam, in a report, "An Economy for the 99\%," published on 16 January 2017, estimates that "just eight men own the same wealth as the poorest half of the world."

In addition, as Oxfam points out in its 2016 Davos report, it will take about $\$ 60$ billion annually to end extreme poverty globally, which is less than one-quarter of the income of the world's top 100 richest people and unless corrective measures are quickly undertaken quickly, the crisis can only get worse in a world. It is to resolve this crisis that the socio-economic theory of akuzurism has been put together. Of course, this is a planet that has more than sufficient resources for the world's wealth to go round! Talk about how some individuals, groups and countries opportune with the means sabotage fairness in the acquisition, distribution and use of world's resources and wealth! These unbecoming social circumstances require a literary theory and that is flipside literary theory.

But, of course, the purview of flipside literary theory extends well beyond poverty issues. No less unbecoming of humanity in modern times is the plight of millions of Arab civilians rendered homeless and expropriated, besides hundreds of thousands who have lost their lives, simply because they had the bad luck of being born at a time and place that left them caught in a crossfire of belligerent geopolitics between regional or world powers in direct or surrogate warfare with each other. Same applies to citizens unlucky to be caught in a crossfire between individuals, cartels, multinational corporations and organizations vying for economic or political control of a country. No less unbecoming too is the plight of victims of human rights abuses by people, groups and foreign countries overtly or covertly interfering with or manipulating critical social processes to achieve selfish ends.

Or still, talk about victims of the European-led transatlantic slave trade $\left(16^{\text {th }}-19^{\text {th }}\right.$ century) where 10 to 15 million Africans were forcibly enshackled and shipped like cargoes to the West Indies and parts of Europe and America and out of every 100 Africans successfully transported, another 40 died en route or in Africa as a consequence. This horrible situation of victims is rivalled only by another slave trade operated by Muslim Arab merchants between 1500 AD and 1900 AD through slave routes linking parts of West Africa and Central Africa with North Africa, with slaves transported across the Sahara desert and the Red Sea, and slave routes across East Africa with slaves transported across the Indian ocean and again the Red Sea.

While flipside literary criticism can be done on any work of literature whatsoever, even on works whose plots are all about bourgeois culture, only works of drama, poetry or prose that distinctively furnish in their plots one or more victims of social existence who will, while still at the margins of society, be opportune to play crucial roles at critical moments in ways that decide the success or failure, life or death of some other characters or social processes on the flipview of society can lay claim to being flipside works. In other words, as all these are unfolding in a plot, flipside characters play these crucial roles without still losing that defining quality as victims of social existence. For the whole length of the plot, they remain constituted as members of flipside society rather than developed to move up to higher forms or flipview society.

The significance of this requirement is to underscore the point that victims of social existence are important to social processes too while being numbered among victims of social existence. But if they should be developed to be numbered among the elite, they are no more victims of social existence and a plot that makes this possible loses every claim to flipside literature.

A classic flipside work that exemplifies this flipside framework is Ikenna Nwadike's The Holy Heist, where Austen, the protagonist, is a mentally challenged young man who evolves to become critical to the success or failure of some powerful individuals, political parties and religious organizations while still remaining a victim of social existence till the end of the narrative. Aminata Sow Fall's The Beggars'Strike, which has been explored by critics such as Mark Beeman, is a remarkable work suitable for flipside criticism. In it, beggars are maltreated like a nuisance and evicted from city streets by bourgeois authorities but by going on a strike designed to make it impossible for the bourgeoisie to thenceforth fulfil the Islamic requirement of almsgiving, they trigger a crisis across the city and upend bourgeois ambitions. However, The Beggars' Strike does not really qualify as a flipside work see- 
ing as the beggars are developed only relative to bourgeois protagonists rather than being themselves protagonized.

A flipside plot can also keep characters who are victims of social existence right where society has kept them at the margins and explore dynamics in relationships among them in ways that establish the huge impacts of those dynamics on the wider society.

With all these in mind, flipside works, thus, provide the understanding that society stands to lose if victims of social existence continue to be ignored, mistreated or undermined seeing as the coin of society is equally constituted by both people on the flipview and those on the flipside. And once again, an aircraft if safer flying on two engines than on one just as reality is not one sided; half of it lies flipside.

\section{REFERENCES}

Akwanya, A. N. Literary Criticism: From Formal to Questions of Method. Nsukka: U of Nigeria P, 2017.

Barthes, Rowland. Elements of Semiology. Trans. Levers A. and Smith C. London: Jonathan Cape, 1967.

Beeman, Mark. "A Sociological Interpretation of Aminata Sow Fall's The Beggars Strike."

Contributions in Black Studies, vol. 9, art. 12, 1992, scholarworks.umass.edu/cibs/vol9/iss1/12.

Carroll, Joseph. "Evolution and Literary Theory." Human Nature, vol. 6, iss. 2, 1995, pp. 119-134. Doi: 10.1007/ BF02734174.

Culler, J. Structuralist Poetics. London: Routledge \& Kegan Paul, 1975.

Eagleton, Terry. Literary Theory: An Introduction. $2^{\text {nd }}$ ed. Minneapolis: U of Minnesota P, 1996.

---. Marxism and Literary Criticism. Taylor \& Francis e-Library, 2006. Ebookstore.

Fiss, Owen, M. "What is Feminism?" Arizona State Law Journal, vol. 26, iss. 2, 1994, pp. 413-428.

Habib, M. A. R. A History of Literary Criticism: From Plato to the Present. Massachusetts: Blackwell Publishing, 2005.
Harris, R. "Translators's Introduction." Course in General Linguistics. F. de Saussure. Translated by Harris R. Chicago: Open Court Classics. 1983.

Hawkes, Terence. Structuralism and Semiotics. London: Methuen, 1977.

---. Structuralism and Semiotics. $2^{\text {nd }}$ ed. New York: Routledge, 2013.

Jameson, F. Marxism and Form: Twentieth Century Dialectical Theories of Literature.

Princeton: Princeton UP, 1972.

Mikell, Gwendolyn. "Introduction." African Feminism: The Politics of Survival in Sub-Saharan

Africa, edited by G. Mikell. Philadelphia: U of Pennsylvania P, 1997.

Nkealah, Naomi. "(West) African Feminisms and Their Challenges.” Journal of Literary Studies, vol. 32, no. 2, 2016, pp. 61-74. Doi: 10.1080/02564718.2016.1198156.

Ogwude, Sophia. O., editor. Writing the Female Image in African Fiction. Ibadan: UP, 2013.

Radford, Gary and Marie Radford. "Structuralism, Post-Structuralism, and the Library: de Saussaure and Foucault." Journal of Documentation, vol. 61, no. 1, 2005, pp. 60-78. Doi: 10.1108/00220410510578014.

Sanusi, Ibrahim Chinade. "Structuralism as a Literary Theory: An Overview." AFRREV LALIGENS, vol. 1, no. 1, 2012, 124-131. www.afrrevjo.net/afrrevlaligens.

Saussure, Ferdinand de. Course in General Linguistics. Translated by Harris R. Chicago: Open Court Classics, 1983.

Taghizadeh, Ali. "A Theory of Literary Structuralism (in Henry James)." Theory and Practice in

Language Studies, vol. 3, no. 2, 2013, pp. 285-292. Doi: 10.4304/tpls.3.2.285-292.

Tihanov, Galin. "Why Did Modern Literary Theory Originate in Central and Eastern Europe? (And Why Is It Now Dead?)" Common Knowledge, vol. 10, no. 1, 2004, pp. 61-80. 